\title{
Pengaruh Penambahan Butanol sebagai Campuran Bahan Bakar Premium terhadap Torsi dan Daya Mesin Bensin dengan Sistem EGR
}

\author{
Firman Lukman Sanjaya ${ }^{1}$, Syarifudin ${ }^{2}$ \\ 1,2Program Studi D III Teknik Mesin, Politeknik Harapan Bersama, Indonesia \\ Email: ${ }^{1}$ sanjaya.firman51@gmail.com, ${ }^{2}$ syarifudin.poltektegal2018@gmail.com
}

\begin{abstract}
ABSTRAK
Peningkatan volume kendaraan menyebabkan tingginya penggunaan bahan bakar fosil dan meningkatnya emisi gas buang. Butanol merupakan bahan bakar terbarukan yang mampu menggantikan bahan bakar fosil. Hal ini karena butanol memiliki karakteristik yang lebih baik dari bensin seperti nilai oktan dan kandungan oksigen yang tinggi. Hal ini mengakibatkan proses pembakaran lebih sempurna pada ruang bakar sehingga torsi dan daya mesin meningkat. Penelitian ini bertujuan untuk mengetahui pengaruh penggunaan butanol terhadap torsi dan daya pada mesin bensin dengan sistem EGR. Pengujian ini dilakukan dengan menggunakan putaran mesin konstan $2500 \mathrm{rpm}$. Prosentase butanol pada bahan bakar premium yaitu 5\%,10\% dan 15\% dari total volume bahan bakar. Hasil pengujian menunjukan bahwa penambahan butanol 5\% pada bahan bakar premium mampu meningkatkan torsi sebesar 4,88\% dengan menggunakan sistem EGR dingin. Daya mesin mengalmi peningkatan tertinggi pada penambahan butanol 15\% dengan menggunakan sistem EGR dingin sebesar 15,6 kW.
\end{abstract}

Kata kunci: butanol, mesin bensin, EGR, torsi dan daya

\section{ABSTRACT}

Increased vehicle volume causes a high use of fossil fuels and increased exhaust emissions. Butanol is a renewable fuel that can replace fossil fuels. This is because butanol has better characteristics than gasoline such as high octane value and oxygen content. This results in a more complete combustion process in the combustion chamber so that engine torque and power increase. This study was to observe the effect of using butanol on torque and power in gasoline engines with the EGR system. This test is carried out using a constant engine speed of $2500 \mathrm{rpm}$. The percentage of butanol in premium fuel is $5 \%, 10 \%$ and $15 \%$ of the total fuel volume. The test results show that the addition of $5 \%$ butanol to premium fuel can increase torque by $4.88 \%$ using a cold EGR system. Engine power experienced the highest increase in the addition of $15 \%$ butanol using a cold EGR system of $15.6 \mathrm{~kW}$.

Keywords: butanol, gasoline engine, EGR, torque and power

\section{Pendahuluan}

Volume kendaraan bermotor mengalami peningkatan setiap tahunnya yang menyebabkan tingginya penggunaan bahan bakar fosil [1]. Tingginya penggunaan bahan bakar mengakibatkan semakin menipisnya persediaan bahan bakar sehingga harga jualnya meningkat dan kelangkaan bahan bakar. Untuk mengatasi permasalahan kelangkaan, perlu adanya energi alternatif yang mampu mengganti bahan bakar bensin dan mampu meningkatkan performa mesin. Butanol merupakan bahan bakar alternatif yang sifat fisiknya lebih baik daripada bensin. Selain itu, butanol memiliki nilai oktan yang tinggi sehingga butanol mampu menahan tekanan yang tinggi dalam silinder. Hal ini dapat meningkatkan daya yang dihasilkan oleh mesin. Butanol juga memiliki panas laten penguapan yang tinggi sehingga bahan bakar menguap lebih baik dalam ruang bakar. Penguapan yang baik akan meningkatkan kecepatan pembakaran dalam silinder [2]. Butanol juga mampu mampu mereduksi emisi CO dan HC. Namun, emisi NOx mengalami peningkatan [3]. Kandungan NOx pada gas buang dapat dikurangi dengan menggunakan EGR (Exhaust Gas Recirculation). EGR bekerja dengan mensirkulasi kembali sebagian dari gas buang dari exhaust manifold kembali ke ruang bakar (combustion chamber). Karena formasi Nitrogen Oxide (NOx) cepat terbentuk pada temperatur tinggi, maka penggunaan sistem EGR akan mengurangi terbentuknya NOx. NOx akan terbentuk ketika campuran nitrogen dan oksigen terpapar pada suhu tinggi. Selain itu, EGR juga mampu meningkatkan performa mesin [4].

Menurut Syarifudin, (2019) [5] pada penelitiannya menjelaskan bahwa tingginya kadar oksigen pada butanol mampu meningkatkan pembakaran dalam silinder dan meningkatkan efisiensi termal. Zheng, dkk. (2017) [6] menjelaskan bahwa butanol sebagai bahan bakar campuran mampu memberikan efek stabilitas pembakaran. Proses 
pembakaran yang baik dapat mereduksi emsi CO, HC namun emisi NOx mengalami peningkatan.

Deepak Agarwal, dkk. (2011) [7] memaparkan bahwa EGR mensirkulasikan kembali gas buang kedalam ruang bakar. Oksigen yang terbawa oleh udara segar yang masuk ruang bakar, sebagian tergantikan oleh gas buang hasil dari sirkulasi tersebut. Hal ini menurunkan konsentrasi oksigen di ruang bakar dan meningkatkan panas spesifik campuran udara masuk yang menghasilkan suhu api lebih rendah sehingga EGR mereduksi NO . Haiqiao Wei, dkk. (2012) [8] menjelaskan bahwa sistem EGR merupakan salah satu langkah efektif untuk menurunkan emisi $\mathrm{NO}_{\mathrm{x}}$. Namun, EGR meningkatkan performa mesin.

\section{Metodologi Penelitian}

Penelitian dilaksanakan di Laboratorium Termofluida Universitas Diponegoro. Penelitian ini bertujuan untuk mengetahui pengaruh penambahan butanol pada premium terhadap torsi dan daya mesin bensin dengan system EGR. Bahan bakar yang digunakan adalah premium yang dilambangkan dengan huruf (P) dan Butanol yang dilambangkan dengan huruf (B). Prosentase campuran bahan bakar tersebut yaitu premium 100\% (P100), premium 95\% dan butanol 5\% (P95B5), premium 90\% dan butanol $10 \%$ (P90B10), dan premium $85 \%$ dan butanol $15 \%$ (P85B15). Karakteristik bahan bakar ditampilkan pada tabel 1. Mesin yang digunakan adalah mesin bensin dengan spesifikasi seperti pada Tabel 2. Percobaan dilakukan dengan kecepatan putaran mesin tetap 2500 rpm. Peralatan uji pada mesin bensin disusun sesuai dengan gambar 1 . Suplai bahan bakar menggunakan sistem EFI Mesin

Tabel 1. Sifat fisik bahan bakar

\begin{tabular}{lccc}
\hline Karakteristik & Satuan & Premium & Butanol \\
\hline Angka Oktan & $\mathrm{RON}$ & 88 & 98,3 \\
Massa Jenis & $\mathrm{Kg} / \mathrm{m}^{3}$ & 744 & 815 \\
Nilai Kalor & $\mathrm{MJ} / \mathrm{Kg}$ & 42,7 & 33,3 \\
Kadar Air & $\% \mathrm{~V}$ & 0,003 & $>5$ \\
Viskositas & $\mathrm{mm}^{2} / \mathrm{s}$ & 0,22 & 2,63 \\
\hline
\end{tabular}

Tabel 2. Spesifikasi mesin

\begin{tabular}{ll}
\hline \multicolumn{2}{c}{ Mesin Toyota Kijang 7K } \\
\hline Mesin tipe & Besin \\
Produksi & Toyota \\
Jumlah silinder & 4 \\
Kapasitas & Mesin $1798 \mathrm{cc}$ \\
Jumlah katup & $(\mathrm{SOHC}) 8 \mathrm{katup}$ \\
Daya maksimum & $94 \mathrm{hp}-5000 \mathrm{rpm}$ \\
Torsi maksimum & $155 \mathrm{Nm}-3200 \mathrm{rpm}$ \\
Sistem bahan bakar & EFI \\
\hline
\end{tabular}

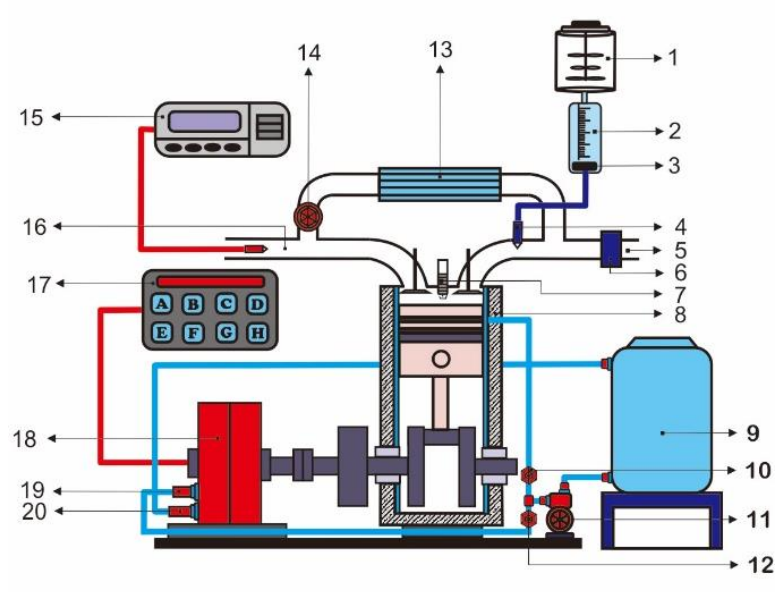

Gambar 1. Eksperimental Setup

\section{Hasil dan Pembahasan}

\subsection{Torsi Mesin}

Pada Gambar. 2, merupakan grafik hasil uji torsi mesin. Pengujian ini menggunakan variasi campuran bahan bakar premium-butanol dengan dan tanpa sistem EGR. Penggunaan butanol secara umum mampu meningkatkan torsi mesin. Peningkatan torsi tertinggi terjadi pada variasi bahan bakar P95B5 sebesar 51,9 N.m. Hal ini menunjukan bahwa penambahan butanol $5 \%$ pada bahan bakar premium dapat meningkatkan torsi mesin hingga 1,94\% dibandingkan premium murni. Peningkatan torsi disebabkan oleh tingginya panas laten penguapan pada butanol sehingga bahan bakar menguap lebih baik diruang bakar. Hal ini menyebabkan proses pembakaran dalam silinder lebih baik [2].

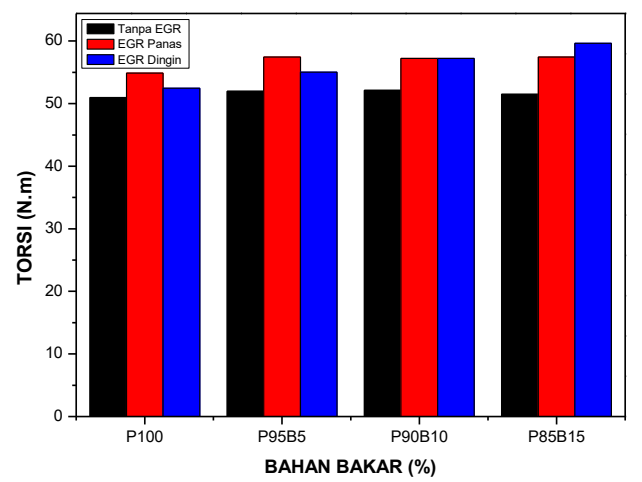

Gambar 2. Torsi untuk variasi campuran bahan bakar dengan tanpa dan sistem EGR pada putaran mesin 2500 Rpm

Penggunaan EGR mampu meningkatkan torsi mesin. Hal ini disebabkan sirkulasi sebagian gas buang yang membawa sisa bahan bakar yang tidak terbakar kembali keruang bakar. Kondisi tersebut membantu pembakaran pada siklus pembakaran berikutnya sehingga EGR meningkatkan torsi mesin [9]. Penggunaan sistem EGR dingin mampu meningkatkan lama pembakaran sehingga tekanan dalam silinder meningkat dibandingkan dengan sistem EGR panas maupun tanpa sistem EGR [10]. 
Peningkatan torsi tertinggi sebesar $4,88 \%$ pada variasi campuran bahan bakar P95B5 dengan menggunakan sistem EGR dingin.

\subsection{Daya Mesin}

Gambar 3. menunjukkan grafik hasil uji daya mesin. Pengujian ini menggunakan variasi campuran bahan bakar premium-butanol dengan tanpa dan sistem EGR. Secara umum, daya mesin mengalami peningkatan pada penggunaan campuran bahan bakar premium-butanol. Peningkatan tertinggi terjadi pada campuran bahan bakar P95B5 yaitu 13,6 kW. Hal ini mempresentasikan bahwa penambahan butanol $5 \%$ mampu meningkatkan daya mesin hingga 1,9\% dibandingkan bahan bakar premium murni. Peningkatan daya mesin disebabkan oleh tingginya nilai oktan pada butanol sehingga bahan bakar mampu menahan tekanan tinggi pada langkah kompresi. Hal ini menyebabkan proses langkah usaha lebih besar dan meningkatkan daya mesin [3]. Penggunaan EGR sedikit meningkatkan daya mesin akibat adanya bahan bakar yang tidak terbakar dalam gas buang yang disirkulasikan masuk ke dalam ruang bakar [11]. EGR tersebut berkontribusi dalam siklus pembakaran berikutnya yang mengakibatkan kenaikan daya mesin. Selain itu, EGR meningkatkan perambatan api sehingga durasi pembakaran mengalami peningkatan yang menyebabkan peningkatan efisiensi termal dan daya mesin [9]. Peningkatan daya mesin tertinggi sebesar $15,6 \mathrm{~kW}$ dengan penambahan butanol $15 \%$ dan menggunakan sistem EGR dingin.

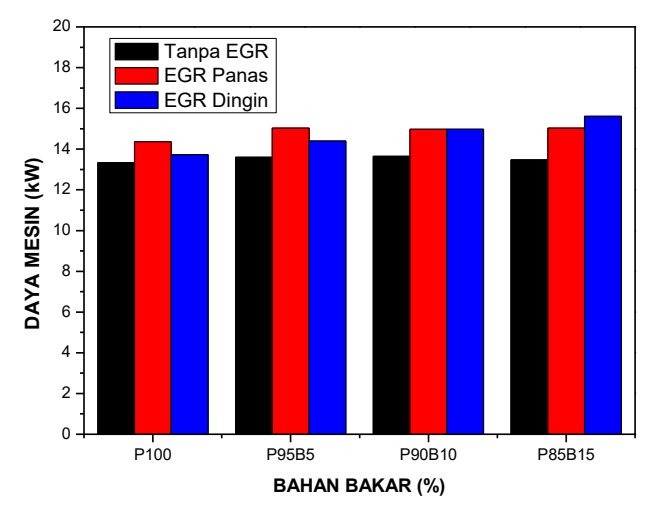

Gambar 3. Daya untuk variasi campuran bahan bakar dengan tanpa dan sistem EGR pada putaran mesin $2500 \mathrm{Rpm}$

\section{Kesimpulan}

Butanol merupakan bahan bakar alternatif yang dapat diperbaharui dan mampu memperbaiki performa mesin. Selain itu butanol juga mampu mereduksi emisi gas buang kendaraan. Dari hasil penelitian ini didapati bahwa penggunaan butanol sebagai bahan bakar alternatif mesin bensin berdampak positif terhadap performa mesin dengan menggunakan sistem EGR. Dari hasil pengujian menunjukan bahwa penambahan butanol $5 \%$ pada bahan bakar premium mampu meningkatkan torsi tertingg sebesar $4,88 \%$ dengan menggunakan sistem EGR dingin. Peningkatan daya mesin tertinggi sebesar 15,6 kW dengan penambahan butanol $15 \%$ dan menggunakan sistem EGR dingin.

\section{Daftar Pustaka}

[1] Syarifudin dan Syaiful, "Daya Dan Emisi Jelaga Dari Mesin Diesel Berbahan Bakar Solar-JatropaButanol," J. Rekayasa Mesin, vol. 14, no. 3, p. 142, 2019, doi: 10.32497/jrm.v14i3.1503.

[2] Yusoff, M. N. A. M., N.W.M. Zulkifli, H.H. Masjuki, M.H. Harith, A.Z. Syahir, M.A. Kalam, M.F. Mansor, A. Azham, L.S. Khuong, 2017, "Performance and emission characteristics of a spark ignition engine fuelled with butanol isomergasoline blends," Transp. Res. Part D Transp. Environ., vol. 57, no. September, pp. 23-38.

[3] Zaharin, M. S. M., N. R. Abdullah, H. H. Masjuki, O. M. Ali, G. Najafi, and T. Yusaf, 2018, "Evaluation on physicochemical properties of isobutanol additives in ethanol-gasoline blend on performance and emission characteristics of a spark-ignition engine," Applied Thermal Engineering, vol. 144. pp. 960-971.

[4] Ladommatos, N., R. Balian, R. Horrocks, and L. Cooper, 1996, "The effect of exhaust gas recirculation on combustion and NOx emissions in a high-speed direct-injection diesel engine," $S A E$ Tech. Pap., vol. 15, no. 10, pp. 1442-1450.

[5] Syarifudin dan Syaiful, 2019, "Pengaruh Penggunaan Energi Terbarukan Butanol Terhadap Penurunan Emisi Jelaga Mesin Diesel Injeksi Langsung Berbahan Bakar Biodiesel Campuran Solar Dan Jatropa," Infotekmesin, vol. 10, no. 1, pp. 18-22.

[6] Chen, Z., Y. Zhang, X. Wei, Q. Zhang, Z. Wu, and J. Liu, 2017, “Thermodynamic process and performance of high n-butanol/gasoline blends fired in a GDI production engine running wideopen throttle (WOT)," Energy Conversion and Management, vol. 152. pp. 57-64.

[7] Agarwal, D., S. K. Singh, and A. K. Agarwal, 2011, "Effect of Exhaust Gas Recirculation (EGR) on performance, emissions, deposits and durability of a constant speed compression ignition engine," Appl. Energy, vol. 88, no. 8, pp. 2900-2907.

[8] Wei, H., T. Zhu, G. Shu, L. Tan, and Y. Wang, 2012, "Gasoline engine exhaust gas recirculation A review," Appl. Energy, vol. 99, no. X, pp. 534544.

[9] Verma, S., L. M. Das, S. C. Kaushik, and S. S. Bhatti, 2019, "The effects of compression ratio and EGR on the performance and emission characteristics of diesel-biogas dual fuel engine", vol. 150. Elsevier Ltd.

[10] Li, T., T. Yin, and B. Wang, 2017, "Anatomy of the cooled EGR effects on soot emission reduction in boosted spark-ignited direct-injection engines," Appl. Energy, vol. 190, pp. 43-56.

[11] Yu, X., Zezhou Guo, Ling He, Wei Dong, Ping 
DOI: 10.35970/accurate.v1i1.175

Sun, Weibo Shi, Yaodong Du,Fengshuo He, 2018, "Effect of gasoline/n-butanol blends on gaseous

engine," Fuel, vol. 229, no. May, pp. 1-10. and particle emissions from an SI direct injection 